\title{
Nephroprotection in Unani Medicine through Herbal Medicine \& their research scope: A Review
}

\author{
Khatoon Rizwana *, Aslam Mohd **, Chaudhary Shahid Shah*** \\ *M.D. Scholar, School of Unani Medical Education and Research (SUMER), Jamia Hamdard, New Delhi, India \\ **Professor \& Head Dept of Ilmul Advia, School of Unani Medical Education and Research (SUMER), Jamia Hamdard, New Delhi, India \\ ***Assistant Professor Dept. Of Saidla, School of Unani Medical Education and Research (SUMER), Jamia Hamdard, New Delhi, India
}

\begin{abstract}
Plants are very potential \& vital source for human health and also used therapeutically in the various kidney disorders due to presence of phytochemical constituents. There are numerous herbs existing that have more pharmacological activities including with nephroprotective activity. Now days herbal drugs are verified \& proved as nephroprotective agents and used for improving renal health, even reverse renal damages. The current review is targeted to explain the Unani \& modern concept of kidney disorders, nephrotoxicity and the list of scientifically proved medicinal plants having nephroprotective activity medicinal plants which used in the treatment of renal disorders.
\end{abstract}

Keywords: Nephroprotection, Unani Medicine, Kidney disorders

Article Info: Received 16 June 2019; Review Completed 23 July 2019; Accepted 29 July 2019; Available online 15 August 2019

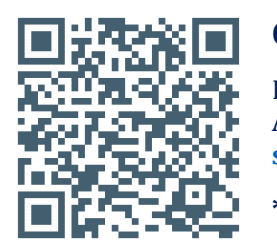

Cite this article as:

Khatoon R, Aslam M, Chaudhary SS, Nephroprotection in Unani Medicine through Herbal Medicine \& their research scope: A Review, Journal of Drug Delivery and Therapeutics. 2019; 9(4-s):687-695 http://dx.doi.org/10.22270/jddt.v9i4S.3306

*Address for Correspondence:

Khatoon Rizwana, M.D. Scholar, School of Unani Medical Education and Research (SUMER), Jamia Hamdard, New Delhi, India

\section{INTRODUCTION:}

The waste products produced in the body due to various metabolic activities must be excreated from the body (1). If they are allowed to accumulate they are injurious to health (2). Kidney is an important organ of the body, which has a natural function of excretion of waste products from the body. Apart from this it controls the volume and composition of the body fluids, for water and virtually all electrolytes in the body, balance between intake and output is maintained in large part by the kidneys (3).. Kidneys are most important channel of excretion for majority of drugs and its metabolites (4), so it always opens up to receive the drugs and other toxins which cause renal damage or renal toxicity (5). Prominent Unani scholars were very much concern about renal disorders. Chronic kidney failure has been described in the classical Unani literature as zaufe Kuliya (6), (7), (8), (9), (10). In Unani System of medicine kidney diseases are caused due to three reasons; Su'i Mizaj-i- Kulya, Su'i Tarkeeb, Tafarruq wa Ittesal (11). There are a unique concept of muqawwiyat (tonics) in unani system of medicine. According to Ibn-e-Rushd (1980) functions of the kidney depends upon its Quwwa. Whenever any Quwwa becomes weak kidney disorders appear. These Quwwa are as follows,
Quwwat-e-Hazima, Quwwat-e-Jaziba, Quwwat-e-Masika, Quwwat-e-Dafia, Quwwat-e-mumayyaza. (7). So herbal drugs are capable to tone up the kidney or other important organs as well as also provide strength to them. In modern medicine concept of kidney disorders can be defined as "a heterogeneous group of disorders which affected the kidney structure and its functions. Now a days, it is accepted that even minor abnormalities in measures of kidney structure and function are related with higher risk for other organ systems as well as mortality, all of which happen far more frequently than kidney failure. Acute \& chronic kidney failure comes in the category of kidney disease which can be life threatening. Reduction in GFR (Glomerular filtration rate) that decreases renal excretory functions is called as renal failure. This is convoyed to a changeable variable by failure of erythropoietin production, vitamin D hydroxylation, and regulation of acid-base balance, regulation of salt \& water balance and blood pressure (12). Nephrotoxicity occurs when kidney-specific detoxification and excretion do not work properly due to the damage or destruction of kidney function by exogenous or endogenous toxicants (effect of toxic chemicals or drugs) (13), (14). Plants are very potential \& vital source for human health and also used therapeutically in the various kidney disorders due to presence of 
phytochemical constituents. There are numerous herbs existing that have more pharmacological activities including with nephroprotective activity. Now a days herbal drugs are verified \& proved as nephroprotective agents and used for improving renal health, even reverse renal damages. The present review is aimed to elucidate the list of nephroprotective medicinal plants, which are scientifically proved in treating renal disorders.

\section{Unani Perspective of Kidney Diseases:}

According to Ibn-e-Rushd (1980) functions of the kidney depends upon its Quwwa. Whenever any Quwwa becomes weak kidney disorders appear. These Quwwa are as follows

$>$ Quwwat-e-Hazima

$>$ Quwwat-e-Jaziba

$>$ Quwwat-e-Masika

$>$ Quwwat-e-Dafia

$>$ Quwwat-e-mumayyaza

In Unani System of medicine kidney diseases are caused due to three reasons; (15), (7);

$>$ Su'i Mizaj-i- Kulya

$>$ Su'i Tarkeeb

$>$ Tafarruq wa Ittesal

1. Su'i Mizaj-i- Kulya (Renal dyscrasia): any alteration in temperament of kidney from normal called as Su'i Mizaj-i-Kulya. If alteration is found in blood (dam) or bile (safra) called as Su'i Mizaj-i- Kulya Haar (Renal hot dyscrasia) and if alteration in phlegm (balgham) or black bile (sauda) known as Su'i Mizaj-i- Kulya Barid (Renal cold dyscrasia) due to this altered temperament there are following diseases found in kidney such as

- Huzāl al-kulya (Reduction in the size of kidney or Renal hypotrophy)

- Du'f al-Kulya (Weakness of kidney)

- Dhayabitus Hārr (Diabetes Mellitus), Dhayabitus bārid (Diabetes Insipidus)

- Hasāh al-kulya (Renal caculus)

- Sudad al-kulya (Renal obstruction)

- Waram al-kulya (Nephritis)

- Dubayala al-kulya (Renal Abscess)

2. Su'i Tarkeeb: any variation in the formation of kidney at the time of intra uterine life (abnormality in genome), Amraze shakal such as Marz Akyas-e Kulya (Polycystic kidney disease), Amraze miqdar such as Huzāl al-kulya (Renal hypotrophy), Amraze adad such as Renal agenesis.

3. Tafarruq wa Ittesal (Renal Damage):

- Quruh al-kulya (Renal ulcers)

- Jarab al-kulya (Renal irritability)

- Rih al-kulya

- Waja' al-kulya (Renal pain)

Amraaze Kulya (Renal Diseases), Causes, Sign \& Symptoms (7), (16), (17)

\begin{tabular}{|c|c|c|c|}
\hline S. No. & Name of the disease & Causes & Sign \& Symptoms \\
\hline 1 & $\begin{array}{l}\text { Huzāl al-kulya (Reduction in the size of } \\
\text { kidney or Renal hypotrophy) }\end{array}$ & $\begin{array}{l}\text { Impaired temperament (hot or cold) of } \\
\text { kidney } \\
\text { Weakness of digestive faculties (Quvvate } \\
\text { hazima) }\end{array}$ & $\begin{array}{l}\text {-Urine become colorless } \\
\text {-Poly urea }\end{array}$ \\
\hline 2 & Du'f al-Kulya (Weakness of kidney) & $\begin{array}{l}\text { Impaired temperament } \\
\text { Dilatation of calyces } \\
\text { Excessive use of diuretics, } \\
\text { More physical efforts. }\end{array}$ & $\begin{array}{l}\text { Frequency of urine } \\
\text { increases } \\
\text { Oliguria } \\
\text { Loss of libido } \\
\text { Headache } \\
\text { Heaviness }\end{array}$ \\
\hline 3 & $\begin{array}{l}\text { Dhayabitus Hārr (Diabetes Mellitus), } \\
\text { Dhayabitus bārid (Diabetes Insipidus) }\end{array}$ & $\begin{array}{l}\text { Impaired hot temperament } \\
\text { Expulsive faculty (Quvvate da'fea) becomes } \\
\text { strong \& weakening of holding faculty } \\
\text { (Quvvate masika) } \\
\text { Dilatation of calyces }\end{array}$ & $\begin{array}{l}\text { Excessive thirst } \\
\text { Excessive \& colorless } \\
\text { urination }\end{array}$ \\
\hline 4 & Hasāh al-kulya (Renal caculus) & $\begin{array}{l}\text { Retaining of Viscous humor inside the } \\
\text { kidneys } \\
\text { Weakening of expulsive faculty of kidney } \\
\text { Any hindrance due to kidney's impaired } \\
\text { temperament }\end{array}$ & $\begin{array}{l}\text { Pain in lumber region } \\
\text { associated with vomiting } \\
\text { Frequency of urination } \\
\text { increases } \\
\text { Dysuria \& anuria } \\
\text { Colorless urination }\end{array}$ \\
\hline 5 & Sudad al-kulya (Renal obstruction) & $\begin{array}{l}\text { Accumulations of mucilaginous viscous } \\
\text { humors } \\
\text { Inflammations (Warm al-kulya) }\end{array}$ & $\begin{array}{l}\text { Pain with renal heaviness } \\
\text { Decreased urine output } \\
\text { Fever due to inflammation }\end{array}$ \\
\hline 6 & Waram al-kulya Hārr (Acute Nephritis) & $\begin{array}{l}\text { Viscous blood (Ghaliz Dam), diluted bile } \\
\text { (Raqeeq Safra) or pure bile (Khalis safra) } \\
\text { suppurated Phlegm (Muta'affin Balgham) or } \\
\text { suppurated blood \& Phlegm both }\end{array}$ & $\begin{array}{l}\text { Fever with chills \& rigor } \\
\text { Pain \& heaviness at the site } \\
\text { of inflammation } \\
\text { Irritation \& restlessness } \\
\text { Dysuria or Anuria }\end{array}$ \\
\hline 7 & $\begin{array}{l}\text { Waram al-kulya Bārid (Chronic } \\
\text { Nephritis) }\end{array}$ & $\begin{array}{l}\text { Predominance of Phlegm (Balgham) \& Black } \\
\text { bile (Sauda) }\end{array}$ & $\begin{array}{l}\text { Mild Fever } \\
\text { Edema }\end{array}$ \\
\hline
\end{tabular}




\begin{tabular}{|l|l|l|l|}
\hline & & & $\begin{array}{l}\text { Pain \& Heaviness at the site } \\
\text { of inflammation }\end{array}$ \\
\hline 8 & Dubayala al-kulya (Renal Abscess) & $\begin{array}{l}\text { Accumulation of pus within the inflamed } \\
\text { kidney, turns into renal abscess }\end{array}$ & $\begin{array}{l}\text { Fever with chills \& rigor } \\
\text { Severe heaviness at the site } \\
\text { of abscess } \\
\text { Viscid and precipitated } \\
\text { urine } \\
\text { Pus discharge in the urine }\end{array}$ \\
\hline 9 & Quruh al-kulya (Renal ulcers) & $\begin{array}{l}\text { Passing of any irritable matter like acute } \\
\text { bilious or salty humor, calculus through } \\
\text { kidney } \\
\text { Due to any injury and abrasion } \\
\text { Boil }\end{array}$ & $\begin{array}{l}\text { Pain without heaviness at } \\
\text { renal angel } \\
\text { Presence of pus, blood and } \\
\text { dead tissue in the urine }\end{array}$ \\
\hline 10 & Jarab al-kulya (Renal irritability) & $\begin{array}{l}\text { Excessive used of that things which increases } \\
\text { the hotness of blood or production of saline } \\
\text { bile or phlegm increases }\end{array}$ & $\begin{array}{l}\text { Pain with irritation in } \\
\text { lumber region } \\
\text { Burning micturition } \\
\text { Presence of pus \& mucoid } \\
\text { casts in the urine }\end{array}$ \\
\hline
\end{tabular}

\section{Modern Concepts of Kidney Diseases:}

"A heterogeneous group of disorders which affected the kidney structure and its functions known as kidney disease. Now a days, it is accepted that even minor abnormalities in measures of kidney structure and function are related with higher risk for other organ systems as well as mortality, all of which happen far more frequently than kidney failure.
Kidney disease differs from the diseases of other organ systems, these diseases habitually "quiet "or sometimes having limited symptoms. The symptoms of renal diseases remains often nonspecific and until late in the course of disease. Thus, there are few kidney-specific "clinical events," which results in a dependence on laboratory procedures to define the major clinical syndromes, so documentation or implication of the duration of abnormalities in laboratory measures are suggested the duration of kidney disease.

Principles for the Definitions of Kidney Diseases and Disorders (18), (19)

\begin{tabular}{|l|l|l|}
\hline Disease/Disorder & Functional criteria & Structural Criteria \\
\hline Acute kidney Injury (AKI) & $\begin{array}{l}\text { Increase in S.Cr by } 50 \% \text { within } 7 \mathrm{~d} \text {, or increase in S.Cr by } 0.3 \\
\mathrm{mg} / \mathrm{dL} \text { within } 2 \mathrm{~d} \text {, or oliguria }\end{array}$ & No criteria \\
\hline Chronic Kidney Disease (CKD) & GFR $<60 \mathrm{~mL} / \mathrm{min}$ for $>3 \mathrm{mo}$. & Kidney damage for $>3 \mathrm{mo}$. \\
\hline Acute Kidney Injury (AKD) & $\begin{array}{l}\text { AKI, or GFR }<60 \mathrm{~mL} / \mathrm{min} / 1.73 \mathrm{~m} 2 \text { for }>3 \mathrm{mo} \text { or decrease in } \\
\text { GFR by } \geq 35 \% \text { or increase in S.Cr by }>50 \% \text { for }<3 \text { mo. }\end{array}$ & Kidney damage for $<3 \mathrm{mo.}$ \\
\hline No known kidney disease (NKD) & GFR $\geq 60 \mathrm{~mL} / \mathrm{min} / 1.73 \mathrm{~m} 2$, stable $\mathrm{S} . \mathrm{Cr}$ & No damage \\
\hline
\end{tabular}

The following most common Kidney disorders and include (20) (19)

- Acute kidney injury (AKI) or Acute renal failure (ARF)

- Nephritic syndrome

- Nephrotic syndrome

- Tubulointerstitial disease

- Vascular disease of the kidney

- Papillary necrosis

- $\quad$ Chronic kidney disease (CKD)

\section{Nephrotoxicity:}

Kidneys are performed many physiological functions of the body such as protection of homeostasis as well as regulation of extracellular atmosphere for example detoxification and elimination of toxic substances (metabolites) and therapeutic agents, these functions are more challenging task for the kidney, that's why kidneys are the most important passage for the entry of any exogenous toxicant into human body. Nephrotoxicity occurs when kidney-specific detoxification and excretion do not work properly due to the damage or destruction of kidney function by exogenous or endogenous toxicants (effect of toxic chemicals or drugs) (13), (14). Nephrotoxins differ in their chemical structure, having different cellular targets and mechanism of cellular injury within the kidney and all of them produce varying degree of kidney damage.

There are many drugs which are responsible for impairment of kidney functions \& leads to renal perfusion or direct nephrotoxicity including antibiotics such as aminoglycoside, vancomycine, antifungal such as amphotericine $B$, immunomodulators such as calcineurin inhibitors, chemotherapeutic agents, cyclosporine, tacrolimus etc. Kidney injury can also occurs within days of initiating therapy with antihypertensive drugs such as ACE inhibitors, $\beta$-blockers, NSAIDS / selective COX-2 inhibitors, Cocaine, occupational toxins (21), (22). Approximately $20 \%$ of hospitalized and non-hospitalized cases are suffering from acute renal failure (ARF) due to drug induced nephrotoxicity (23), (24), (25). The prevalence of drug-induced nephrotoxicity may be 66 percent high in the older adults (26). 


\section{Mechanisms of actions of drug induced nephrotoxicity:}

Drug induced nephrotoxicity can be explained by the following different pathogenic mechanism such as (27), (28).

$>$ Changed intra-glomerular hemodynamics,

$>$ Tubular cell toxicity,

I. Changed intra-glomerular hemodynamics: The pathogenic mechanism of changed by the following flow chart;

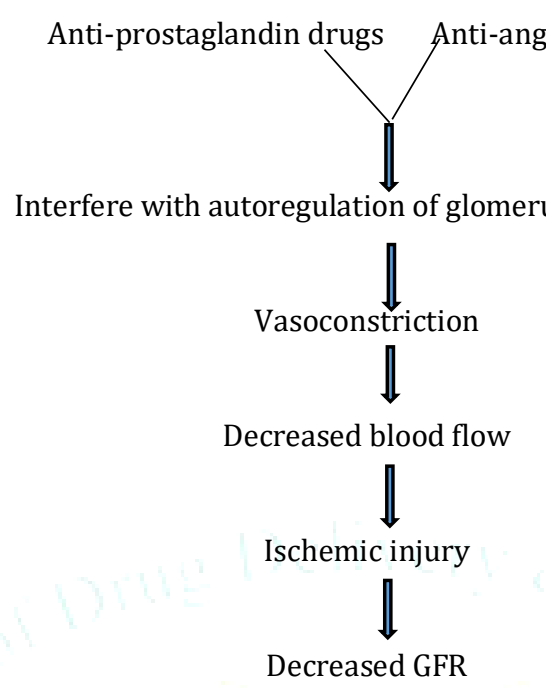

- Nephrotoxic Drugs: NSAIDs, ACE Inhibitors, Cyclosporine, Tacrolimus (29),

II. Tubular cell toxicity: The following flow chart explained the pathogenic mechanism of tubular cell toxicity; (30), (31) Nephrotoxic drug (Amphotericin B,antiretrovirals)

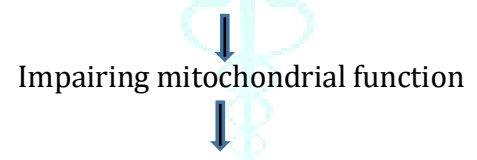

Interfering with tubular transport,

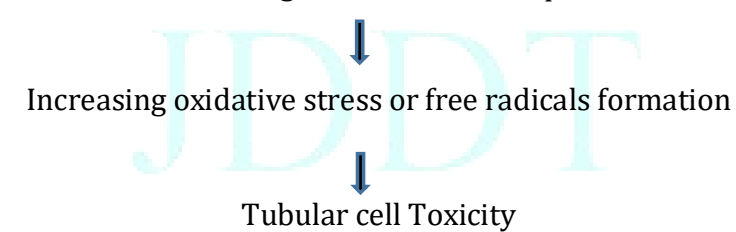

- Nephrotoxic drugs: Antimicrobials, Amphotericin B, Beta-lactam antibiotics, Rifampicin, Adefovir, Cidofovir, and Contrast dye, Zoledronate (32), (33), (34), (35), (31), (36)

III. Crystal nephropathy: Nephrotoxic drugs caused renal impairment by the production of urine insoluble crystals within the distal tubular lumen explained following flow chart (31),

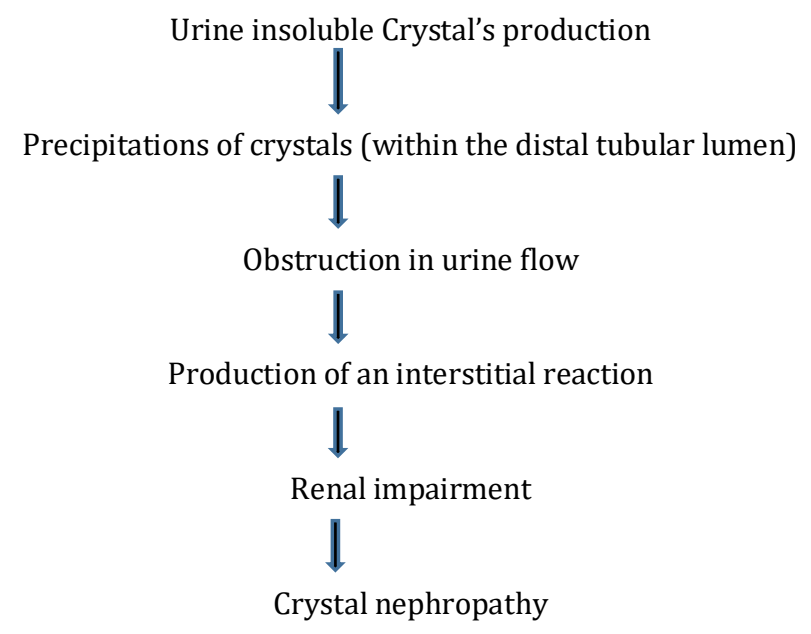


- $\quad$ Nephrotoxic Drugs: Foscornet, Methotrexate, Triamterene, Ganciclovir (35), (31), (37).

IV. Rhabdomyolysis: It is the condition in which rapidly damaged \& break down of skeletal muscles tissue, these damaged skeletal muscles cells such as myoglobin released into bloodstream and causes kidney injury. The pathogenic mechanism explained through following flow chart; (38)

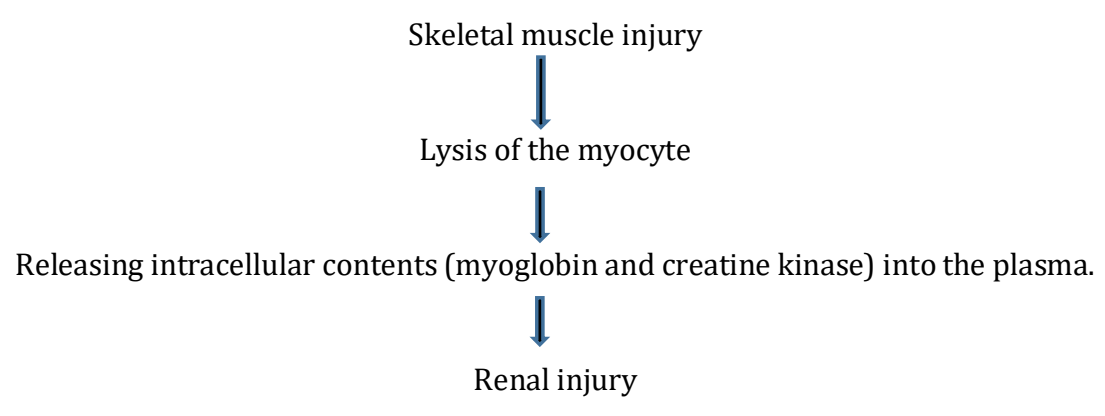

(Direct renal toxicity, tubular obstruction, and modifications in GFR.)

- $\quad$ Nephrotoxic drugs: Amitryptiline, Diphenhydramine, Doxylamine, Benzodiazepines, Statins, Methodone (39), (38)

V. Thrombolytic Microangiopathy: Thrombolytic microangiopathy is due to formation of thrombi in the microcirculation which leads to renal injury, following flow chart described pathogenic mechanism of thrombolytic microangiopathy (40)

Formation of thrombus in the microcirculation

Immune-mediated reaction

I

Direct endothelial toxicity

- Nephrotoxic drugs: Cyclosporin, Clopidogrel, Mitomycin C, Quinine (41), (40)

VI. Inflammation: Inflammatory changes occurs mostly in the glomerulus, renal tubular cells, and the surrounding interstitium due to nephrotoxic drugs \& fibrosis and renal scarring takes place.

Glomerulonephritis is an inflammatory condition caused primarily by immune mechanisms and is often associated with proteinuria in the nephrotic range (35).

- Nephrotoxic drugs: Allopurinol, Aspirin Acetaminophen, Acyclovir, antibiotics, Beta-lactam, Chinese medicines Quinolones, Rifampicin, Sulfonamides, Cisplatin, Loops \& thiazide diuretics (35), (31), (42)

\section{Research scope of herbal medicine:}

Plants are very good for human health and used therapeutically in the various kidney disorders because presence of their chemical components and medicinal properties (43). Lots of herbs have been proven to be capable as Reno-protective agents but some of them are claimed to be Nephroprotective, there are so many researches available which proves the Nephroprotective effect of these herbal drugs such as

\section{Nephroprotective Action of Phoenix dactylifera.in} Gentamicin-Induced Nephrotoxicity

Aqueous extract of date flash has a prophylactic action on gentamicin induced nephrotoxicity in pretreated animals, proved by a significant decrease in the plasma concentrations of creatinine and urea \& in an increase in the body weight of the animals during the treatment period. Aqueous extract of date flash also has a curative effect when it was given combined with gentamicin which proved by a significant decreased in increased biochemical parameters. Acute and chronic toxicity study also has been done by an oral administration of graded doses of the aqueous extracts of the date flesh and depths to male Wistar rats, proved that the given extract was safe for the animal (44).

\section{Nephroprotective Effect of Kabab Chini (Piper cubeba) in Gentamycin-Induced Nephrotoxicity}

The pre- and post-treated animal groups was taken powder of test drug in suspension form at $810 \mathrm{mg} / \mathrm{kg}$ and 1220 $\mathrm{mg} / \mathrm{kg}$ orally. The assessment parameters for nephroprotective effect are based on biochemical markers such as serum urea and creatinine levels as well as histopathological analysis of the treated kidney. Biochemical markers of renal function were found to be significantly lower in the pre-treated group in comparison the control group, while mild tubular damage shown in histological analysis. In the same way, there were a significant decrease in serum urea and creatinine levels in the post-treated animals in comparison to negative control group, moderate degree of tubular necrosis seen in the histopathological examination. So $\mathrm{KC}$ has a significant amount of nephroprotective activity which proved by the examination of biochemical markers of kidney function and the histopathological features pre-treated and post-treated groups (45).

\section{Nephroprotective Action Of Peucedanum Grande Against Cadmium Chloride Induced Renal Toxicity In Wistar Rat}

Nephroprotective effect of $P$. grande against $\mathrm{CdCl} 2$ induced nephrotoxicity was assessed by the estimation of biochemical markers, antioxidant enzyme activities and histopathological changes. Animals were taken pretreatment of $P$. grande at a dose of 60 and $120 \mathrm{mg} / \mathrm{kg}$ b.wt orally against the renal nephrotoxicity produced by $\mathrm{CdCl} 2$ at a dose of $3 \mathrm{mg} / \mathrm{kg}$ b.wt. CdCl2 induced deteriorative effects were prevented by Pretreatment with $P$. grande, through a protective mechanism, which involved Improved deterioration i.e. increased oxidative stress as well as 
histopathological changes i.e. damaged renal tissues against $\mathrm{CdCl} 2$ administration. BUN, creatinine significantly lower in pretreated rats with $P$. grande in comparison to that animals which getting only $\mathrm{CdCl} 2$. The present study concluded $P$. grande has potent nephroprotective activity through a protective mechanism \& this activity of $P$. grande might be due to its free radical scavenging activity (46).

\section{Diuretic and nephroprotective effect of Jawarish Zarooni Sada-a polyherbal unani formulation}

Ethanol and aqueous extracts of jawarish zarooni sada (JZS) at $300 \mathrm{mg}$ each were examined as diuretic activity by calculating the total urine output over a period of $6 \mathrm{~h}$ in the present study. Sodium and potassium level in urine sample was also estimated. Nephrotoxicity was investigated by administration of JZS along with gentamicin at high dose (40 $\mathrm{mg} / \mathrm{kg}$ ) and elevated biochemical markers such as urea and serum creatinine he study proved that JZS has significant diuretic and nephroprotective properties (47)

5. Protective effects of 'Khamira Abresham Hakim Arshad Wala', a unani formulation against doxorubicin-induced cardiotoxicity and nephrotoxicity

Doxorubicin produced a marked nephrotoxicity, as shown by in the elevation serum enzymes such as of AST, LDH, kidney biochemical markers i.e. BUN, creatinine, and, depletion in stress marker such as MDA, GSH level \& catalase activity Khamira abresham Hakim Arshad wala showed nephroprotective effect against doxorubicin-induced nephrotoxicity, there was a significant enzymatic changes in serum as well as damaged renal tissues in pretreated group of animals. The results of present study reveals that the elevation \& depletion in above serum enzymes, biochemical and stress markers as well renal damage were significantly $(p<0.01)$ improved after the treatment of Khamira Abraham Hakim Arshadwala (48)

\section{Nephroprotective Effect of Echinodorus macrophyllus Micheli on Gentamicin-Induced Nephrotoxicity in Rats}

Current study on "Nephroprotective Effect of Echinodorus macrophyllus Micheli on Gentamicin-Induced Nephrotoxicity in Rats" shown that gentamicin induced nephrotoxicity increased biochemical markers such as polyuria, decreased in GFR \& morphological changes also. On treatment with extract Echinodorus macrophyllus Micheli (EM) along with gentamicin reversed all above alterated parameters \& morphological changes were also not detected. EM extract also produced a dose-dependent decrease in urine elimination. So the study concluded that EM has nephroprotective potential \& EM can used therapeutically an incidence of GM-induced acute kidney injury (49).

\section{Phytochemical, pharmacological evaluation of Morinda pubescens J.E.Sm. Bark extract for nephroprotective activity}

Water extract Morinda pubescens J.E. Sm. (WEMp) of silymarin, and its isolated ethyl acetate fraction compound (ISLTD mp-B) significantly increased the biochemical markers of kidney such as albumin, protein, body weight, and urine volume \& decreased kidney serum creatinine, urea, uric acid, blood urea nitrogen, kidney weight with a significant reduction in gentamicin induced toxicity. The study also reveals that (WEMp) and (ISLTD mp-B) treated group increased urine output than normal which helped to dilutes the concentration of kidney function parameters such as S. creatinine, urea, uric acid, and blood urea nitrogen
Thus, kidney's toxins, increased biochemical markers or waste products are flushed out via the urine and reduced the chances or prevent the renal toxicity. The Reno protective activity of bark extracts may be due to the antioxidant activity, due to the existence of secondary metabolites i.e. tannins, flavonoids and phenolic compounds, etc. (50).

8. Evaluation of Nephroprotective Activity of Ethanolic Extract of Annona reticulata in Gentamicin and Cisplatin Induced Nephrotoxicity in Rats

In the study "Evaluation of Nephroprotective Activity of Ethanolic Extract of Annona reticulata in Gentamicin and Cisplatin Induced Nephrotoxicity in Rats" toxicant group (2nd and 5th) gentamicin \& cisplatin treated has severe nephrotoxicity evidence by an increment concentration of serum, urea, Creatinine, Uric acid, Total protein and Urine Urea, uric acid, creatinine in comparison to normal control (group 1). The increased biochemical parameters improved by the treatment of ethanolic extract of aerial parts of Annona reticulata \& showed Nephroprotection because of presence of phyto chemical constituents (51).

9. Evaluation for nephroprotective activity of ethanolic extract of Allium cepa Linn. In gentamicin-induced nephrotoxicity in rats

Treatment with the A. cepa Linn. Has shown significant $(p<0.01$ and $p<0.001)$ dose-dependent improvement in the body weight at the dose of 200 and $400 \mathrm{mg} / \mathrm{kg}$ and also shown significant improvement by protecting the kidney from the oxidative stress. It is also identified that treatment with A. cepa significantly lowered the level of serum creatinine, total protein when compared with the toxic group. Conclusion: Nephroprotective activity of EEAC treatment was found compared with the standard group (Vitamin E - 250 $\mathrm{mg} / \mathrm{kg}$ ) and control group against the toxic control group animals in parameters including serum creatinine, total protein, kidney weights, and body weights. The histopathological studies were also evinced the protective effect of EEAC. (52).

\section{Nephroprotective Effect of Aqueous Extract of Pimpinella anisum in Gentamicin Induced Nephrotoxicity in Wistar Rat}

Co-administration of Pimpinella anisum extract with gentamicin decreased the following rise parameters such as serum urea, serum uric acid, and serum creatinine and blood urea nitrogen in a dose dependent manner. Gentamicin treated group shown nephrotoxicity proved by elevated serum urea, serum uric acid, serum creatinine and blood urea nitrogen $(107.5 \pm 16.92 \mathrm{mg} / \mathrm{dl}, \quad 0.8 \pm 0.09 \mathrm{mg} / \mathrm{dl}$, $3.05 \pm 0.29 \mathrm{mg} / \mathrm{dl}$, and $47.8 \pm 9.07 \mathrm{mg} / \mathrm{dl}$ ) respectively in comparison to the saline treated groups. Gentamicin treated group also shows histopathological changes such as epithelial loss with deep granular degeneration in rats, while water extract of Pimpinella anisum decreased the severity of gentamicin-induced renal damage. So the study concluded, that water extract of Pimpinella anisum reveals nephroprotective effect in gentamicin induced renal damage (53).

11. Nephroprotective Activity of Methanolic Extract of Lantana camara and Squash (Cucurbita pepo) on Cisplatin-Induced Nephrotoxicity in Rats and Identification of Certain Chemical Constituents of Lantana camara by HPLC-ESI-MS.

Methanolic (defatted) extract of the two plants (Lantana camara and Cucurbita pepo) have nephroprotective effect on cisplatin-Induced nephrotoxicity in rats. Ethyl acetate and 
butanolic derivative of methanolic extract of $L$. camara also had high nephroprotective activity. The study also revealed that the nephroprotective effect of these extract because of the presence secondary metabolites or plants phytochemical constituents such as phenolic acid derivatives, favonoids, phenylethanoids and Iridoids etc and phytochemicals analyses by the use of HPLC-ESI-MS technique (54).

\section{Nephroprotective Effect of Sonchus oleraceus Extract against Kidney Injury Induced by Ischemia-Reperfusion in Wistar Rats}

Sonchus oleraceus Extract (S.O.e) significantly reduced the higher level of kidney biochemical parameters such as urea nitrogen (BUN), creatinine, malondialdehyde (MDA), and pro-inflammatory cytokines \& lowered the SOD level in Ischemia-Reperfusion (I/R) treated animal groups than the sham group. Tubular epithelial necrosis in the medulla and cortex were seen on histopathological examination in I/R treated group. While pretreatment with S.O.e \& treatment in combination of S.O.e and I/R reduced the $I / R$ induced increased renal biochemical parameters included BUN, creatinine, MDA, and proinflammatory cytokines induced, SOD as well as discontinuous necrosis in the medulla but no necrosis in the cortex on histopathological examinations. So the present study concluded that S.O.e has neither nephrotoxicity nor hepatotoxicity in spite of Nephroprotection pretreatment with S.O.e (55).

\section{Nephroprotective Effect of Camel Milk and Spirulina platensis in Gentamicin-Induced Nephrotoxicity in Rats}

Gentamicin treated animal group significantly showed increased levels of urea, creatinine and malondialdehyde, decreased level of glutathione (GSH) \& extensive tubular necrosis present in histopathological examination. While extract of Camel Milk (CM) and Spirulina platensis (CP) and their combination (SPCM) treated animal group showed a significant improvement in these increased biochemical parameters, stress marker \& histopathological changes (56).

\section{Phytochemical and Nephroprotective Activity of Eclipta prostrata against Gentamicin Induced Nephrotoxicity in Wistar Rats}

In the present study "Phytochemical and Nephroprotective Activity of Eclipta prostrata against Gentamicin Induced Nephrotoxicity in Wistar Rats" showed a significant nephrotoxicity in nephrotoxic group (Group II) by increased in S. urea, S. creatinine, and S. uric acid, BUN \& kidney weight, while a major reduction has been shown in all these parameters in extract treated group which compared with standard (Cystone) group (Group V). Preliminary phytochemical screening of leaves of Eclipta prostrata reveals the presence of secondary metabolites such as terpenoids, glycosides, alkaloids, sterol, flavonoids, volatile oils and Saponins etc. (57).

\section{Acute nephroprotective and antioxidant activities of aqueous leaf extract of Plectranthus amboinicus (Roxb.) grown in Sri Lanka}

The current study has been shown that ADR produced nephrotoxicity by the elevated biochemical parameters such as S. in rats. The elevated S. creatinine level significantly decreased after treatment with aqueous extract of leaf of $P$ ambonicus ( $400 \mathrm{mg} / \mathrm{kg}$ body wt.) in comparison to control group. Glomerular and tubular functions of the kidney was measured by the $\beta 2$-microglobulin. Concentration of $\beta 2$ microglobulin increased $50 \%$ in the control (nephrotoxic) group rats in comparison to the control group (healthy) (p0.05). The results of the study concluded that, P. ambonicus is reduced very fast the raised level of $\beta 2-$ microglobulin in the comparison \& extract of plant leaf also reduced the increased levels of S. Albumin, total protein as compared to standard drug, proved nephroprotectivity of the leaf extract of $\mathrm{P}$. amboinicus against ADR induced nephrotoxicity (58).

\section{Antioxidant and nephroprotection activities of Combretum micranthum: A phytochemical, in-vitro and exvivo studies}

End stage renal disease is a most common \& serious complications of diabetic nephropathy. A significant dose dependent inhibition $(\mathrm{P}<0.001)$ was found in lipid peroxidation induced by ferric chloride-ascorbic acid after treatment with CM extract. Human embryonic kidney cell (HEK-293) was used as in-vitro model for glucose induced toxicity for diabetic nephropathy in this study. The present study revealed that a significant morphological changes such as cell shrinkage, rounded cell shape and cytoplasmic vacuolation after taking the high glucose $(100 \mathrm{mM})$ for $72 \mathrm{~h}$, but the cell viability (10 to $23 \%$ ) improved after taking treatment with 10 and $25 \mathrm{mg} / \mathrm{mL}$ CM extract in comparison to high glucose control. The results of study proved that $\mathrm{C}$. micranthum has potent antioxidant and nephroprotective activity (59).

\section{Nephroprotective activity of Combretum micranthum G. Don in cisplatin induced} nephrotoxicity in rats: In-vitro, in-vivo and in-silico experiments

Recent study on "Nephroprotective activity of Combretum micranthum G. Don in cisplatin induced nephrotoxicity in rats: In-vitro, in-vivo and in-silico experiments" reveals that Cisplatin produced a significant increase in cell death with changes in normal cellular morphology in HEK-293 cells. The study also revealed that CP and CM extract treated HEK293 cells shows a significant improvement in cell growth which indicate CM-extract has high cytoprotective activity in comparison to $\mathrm{CP}$ extract while CP-treated rats showed a characteristic clinical and pathological symptoms i.e. increased relative kidney weight, altered kidney function parameters such as creatinine, urea, uric acid, total protein, albumin and electrolytes against cisplatin induced cytotoxicity, hence proved that $\mathrm{CM}$ extract contain Nephroprotective activity (60)

\section{Conclusions:}

The above review concludes that herbal drugs are very useful for kidney health. It is mentioned in classical Unani literature that various single as well as compound formulations are used extensively as diuretics (Mudir e baul), kidney and bladder tonics ( Muqawwi e Gurda wa Masana) and lithotripsic (mufattit hisaat) since ages. A number of researches has been performed in this field but further validation with proper pre-clinical \& clinical trials are needed so the herbal formulations as well as the single drugs could be accepted globally and help the mankind with least adverse effects in various renal disorders.

\section{References:}

1. V.M A. Textbook of physiology. 5th ed.; 2005.

2. N.M M. Human Physiology. 6th ed.; 2010.

3. Hall G\&. Textbook of medical pharmacology. 10th ed.; 2001.

4. K.D. T. Essential of Medical Pharmacology. 6th ed.; 2006.

5. M.A. P. Renal vulnerability to drug toxicity. Clinical Journal of the 
American Society of Nephrology. 2009; 4(7): p. 1275-83.

6. Ibn Rushd AWMB. Kitabul kulliyat (Urdu translation) New Delhi: CCRUM; 1980

7. Sina I. Al-Qanoon Fit-Tib. 2nd ed. Kantoori HGH, editor. NewDelhi: Idara e Kitabu-Shifa; 2014.

8. Zohar I. Kitabul Taisir Fil Mudawat wa Tadabeer (Urdu translation) New Delhi: CCRUM; 1986

9. M.H. J. Zakheera Khawarazm Shahi (Urdu Translation) Lucknow: Munshi Nawab Kishore; 1903.

10. M.A. K. Ikseere Azam (Urdu translation) Rawalpindi Pakistan: Tibbi company; 1940.

11. Roohi Zaman AAMJGSaGA. Nephroprotective effect of Beekh Kasni (Roots of Cichorium intybus) in the form of methanolic and aqueous extract in Gentamycin induced rat models. Journal of Pharmacognosy and Phytochemistry. 2017; 6(3): p. 337-341.

12. Kumar P. cM. Kumar \& clark's clinical Medicine. 7th ed. Edinburgh: Elsevier Limited; 2009.

13. Kim S.Y. MA. Drug Induced Nephrotoxicity and Its Biomarkers. Biomolecule \& Therapeutics. 2012; 20(3): p. 268-272

14. Sun YK, Aree M. Drug-induced nephrotoxicity and its biomarkers. Biomol Ther. 2012; 20(3): p. 268-272.

15. Roohi Zaman AAMJGSaGA. Journal of Pharmacognosy and Phytochemistry.

16. Deen HMku. Al Aksire Azam New Delhi: Aijaz Publishing House; 2010.

17. Anonymous. Tarjuma Sharh e Asbab New Delhi: CCRUM; 2010.

18. Zoltan Endre RL. KHA-CARI Adaptation of KDIGO Clinical Practice Guideline for Acute Kidney Injury. Asian Pacific Society of Nephrology. 2014; 19: p. 261-5

19. Donald LW, Hasan B. Approach to the patient with renal disease. In Lee Goldman AIS. Goldman's Cecil Medicine. 25th ed.: Elsevier saunders; 2016. p. 708.

20. Anonymous. Definition and Classification of Kidney Diseases. 2013; 61(5): p. 686-688

21. Shahrbaf FG AF. Drug-induced renal disorders. Journal of renal injury prevention. 2015; 4(3): p. 57

22. Millena DB, Danielly BS, Fernando AB, Adriano MMR, Maria APM. Drug-induced nephrotoxicity and dose adjustment recommendations: Agreement among four drug information sources. Int. J. Environ. Res. Public Health. 2015; 12: p. $11227-$ 11240 .

23. Kaufman J DMPBHR. Community-acquired acute renal failure. Am J Kidney Dis. 1991; 17(2): p. 191-198.

24. Nash K HAHS. Hospital-acquired renal insufficiency. Am J Kidney Dis.. 2002; 39(5): p. 930-936.

25. R. B. The epidemiology of acute renal failure: 1975 versus 2005. Current opinion in critical care. 2006; 12(6): p. 557-60.

26. Kohli HS BMMTea. Treatment-related acute renal failure in the elderly: a hospital-based prospective study. Nephrol Dial Transplant. 2000; 15(2): p. 212-217.

27. Schetz M DJGSGT. Drug-induced acute kidney injury. Curr Opin Crit Care. 2005; 11(6): p. 555-565.

28. RA. Z. Pathogenetic mechanisms in nephrotoxic acute renal failure.. Semin Nephrol. 1997; 17(1): p. 3-14.
29. Schoolwerth AC SDBBWC. Renal considerations in angiotensin converting enzyme inhibitor therapy: a statement vascular Disease and the Council for High Blood Pressure. Research of the American Heart Association. Circulation. 2001; 104(16): p. 1985-1991.

30. RA. Z. Pathogenetic mechanisms in nephrotoxic acute renal failure. Semin Nephrol. 1997; 17(1): p. 3-14.

31. Markowitz GS P. MA. Drug-induced renal failure: a focus on tubulointerstitial disease. Clin Chim Acta. 2005; 351(1-2): p. 3147.

32. Schnellmann RG KK. Pathophysiology of nephrotoxic acute renal failure.. In: Berl T, Bonventre JV, eds. Acute Renal Failure. Philadel phia, Pa.: Blackwell Science. 1999; 1.

33. Palmer BF NE. Renal dysfunction complicating the treatment of hypertension. J Med. 2002; 347(16): p. 1256-1261.

34. Olyaei AJ dMABW. Immunosuppressant-induced nephropathy: pathophysiology, incidence and management. Drug Saf. 1999; 21(6): p. 471-488.

35. MA. P. Drug-induced nephropathy: an update. Expert Opin Drug Saf. $2005 ; 4(4)$ : p. $689-706$

36. Markowitz GS FPSJ. Toxic acute tubular necrosis following treatment with zoledronate (Zometa). Kidney Int. sis following treatment with zoledronate (Zometa). Kidney Int. 2003; 64(1): p. 281-289.

37. MA. P. Crystal-induced acute renal failure. Am J Med. 1999; 106(4): p. 459-465

38. Coco TJ KA. Drug-induced rhabdomyolysis. Curr Opin Pediatr 2004; 16(2): p. 206-210.

39. Huerta-Alardín AL VJMP. review: rhabdomyolysis-an overview for clinicans. Bench-to-bedside. Crit Care. 2005; 9(2): p. 158169.

40. Pisoni R RPRG. Drug-induced thrombotic microangiopathy: incidence, prevention and management. Drug Saf. 2001; 24(7): p. 491-501.

41. Manor SM GGIS. Clopidogrel-induced thrombotic thrombocytopenic purpura-hemolytic uremic syndrome after coronary artery stenting. Pharmacotherapy. 2004; 24(5): p. 664667.

42. Markowitz GS AGFP. Collapsing focal segmental glomerulosclerosis following treatment with high-dose pamidronate. J Am Soc Nephrol. 2001; 12(6): p. 1164-1172.

43. Shelke TT KRAPBVJKKBOR. Nephroprotective activity of ethanolic extract of dried fruits of Pedalium murex Linn. Journal of Cell and tissue research. 2009; 9(1): p. 1687.

44. Al-Qarawi AA ARHMHABEMS. Nephroprotective action of Phoenix dactylifera.in gentamicin-induced nephrotoxicity. Pharmaceutical Biology. 2008; 46(4): p. 227-30.

45. Ahmad QZ JNAG. Nephroprotective effect of Kabab chini (Piper cubeba) in gentamycin-induced nephrotoxicity. Saudi Journal of Kidney Diseases and Transplantation. 2012; 23(4): p. 773.

46. Aslam M ASDRJKUSAANSBJWASMSS. Nephroprotective action of Peucedanum grande against cadmium chloride induced renal toxicity in wistar rats. EXCLI journal. 2012; 11: p. 444-52.

47. Afzal M KNGAIAIM. Diuretic and nephroprotective effect of Jawarish Zarooni Sada-a polyherbal unani formulation.. Journal of ethnopharmacology. 2004; 91(2-3): p. 219-23.

48. Nazmi AS ASRAAMPKNA. Protective effects of 'Khamira Abresham Hakim Arshad Wala', a unani formulation against doxorubicin-induced cardiotoxicity and nephrotoxicity. 
Toxicology mechanisms and methods. 2011; 21(1): p. 41-7.

49. Portella VG CGDLPLCGCMBMVM. Nephroprotective effect of Echinodorus macrophyllus Micheli on gentamicin-induced nephrotoxicity in rats. Nephron extra. 2012; 2(1): p. 177-83.

50. Jedage HD MK. Phytochemical, pharmacological evaluation of Morinda pubescens JE Sm. bark extract for nephroprotective activity. Ayu. 2016; 37(3-4): p. 244.

51. Devi MA DMNBPK. Evaluation of nephroprotective activity of ethanolic extract of Annona reticulata in gentamicin and cisplatin induced nephrotoxicity in rats. Journal of Pharmaceutical Sciences and Research.. 2016; 8(9): p. 995.

52. Chinnala KM APVVEM. Evaluation for nephroprotective activity of ethanolic extract of Allium cepa linn. In gentamicin-induced nephrotoxicity in rats. Asian J Pharm Clin Res. 2017; 10(3): p. 356-359.

53. Aiswarya N CVTSRK. Nephroprotective effect of aqueous extract of Pimpinella anisum in gentamicin induced nephrotoxicity in wistar rats. Pharmacognosy Journal. 2018; 10(3).

54. Abdel-Hady H,ESMM,AHAA,HMM,AHAM,AT,AHESS,ALEESaMEA. Nephroprotective Activity of methanolic extract of Lantana camara and squash (Cucurbita pepo) on cisplatin-induced nephrotoxicity in rats and identification of certain chemical constituents of Lantana camara by HPLC-ESI. Pharmacognosy Journal. 2018; 10(1).

55. Torres-González L CPEPQMAGGMELPRECPP. Nephroprotective effect of sonchus oleraceus extract against kidney injury induced by ischemia-reperfusion in wistar rats. Oxidative medicine and cellular longevity. 2018;: p. 1-7.

56. Hamad EM MHAIASA.2J1, 559-65. 1. Nephroprotective Effect of Camel Milk and Spirulina platensis in Gentamicin-Induced Nephrotoxicity in Rats. Int J Pharmacol. 2018; 14: p. 559-65.

57. Ahmad F ASAAOAMA. Phytochemical and Nephroprotective Activity of Eclipta prostrata against Gentamicin Induced Nephrotoxicity in Wistar Rats. International Journal of Pharma Research and Health Sciences. 2018; 6(2): p. 2559-64.

58. Amarasiri AM AAJKML. Acute nephroprotective and antioxidant activities of aqueous leaf extract of Plectranthus amboinicus (Roxb.) grown in Sri Lanka. Journal of Pharmacognosy and Phytochemistry. 2018; 7(4): p. 155-61.

59. Kpemissi M EGKVVPAAKVSBST NMKAK. Antioxidant and nephroprotection activities of Combretum micranthum: A phytochemical, in-vitro and ex-vivo studies. Heliyon. 2019; 5(3): p. 1-31.

60. Kpemissi M EGKVVNMTMCVHJBSTNSDPT,iv. Nephroprotective activity of Combretum micranthum G. Don in cisplatin induced nephrotoxicity in rats: In-vitro, in-vivo and in-silico experiments. Biomedicine \& Pharmacotherapy. 2019; 116(1).
61. Kristina MY. Acute Kidney Injury: An Overview Of Pathophysiology and Treatments. American Nephrology Nurses' Association. 2011; 38(1): p. 13-19.

62. David PB, Melissa DA, Timothy AS. Pathophysiology of acute kidney injury. Compr Physiol. 2012; 2(2): p. 1303-1353.

63. Marcus G, Gianna MK. Chronic kidney disease: importance of early diagnosis,Chronic kidney disease: importance of early diagnosis,approach to improve outcomes in patients not yet on dialysis. J Bras Nefrol. 2011; 33(1): p. 74-87.

64. Andrew SL, Joseph C. Chronic kidney disease. Lancet. 2012; 379: p. 165-180.

65. Jha V, Guillermo GG, Kunitoshi I, Zuo L, Saraladevi N, Brett P, et al. Chronic kidney disease: global dimension and perspectives. Lancet. 2013; 382: p. 260-272.

66. Michael E, Andrew ZF, John CS. Approach to the patient with kidney disease. In Taal MW, Cherton GM, Marsden PA. Brenner \& Rector's The kidney. 10th ed.: Elsevier; 2015. p. 773.

67. Hsu C, Ordonez J, Chertow G, Fan D, CE McCulloch AG. The risk of acute renal failure in patients with chronic kidney disease. International Society of Nephrology. 2008; 74: p. 101-107.

68. William LH. Nephrotoxicity of several newer agents. Kidney International. 2005; 67(SI 94): p. 107-109.

69. William OB. The role of transport in chemical nephrotoxicity. Toxicologic Pathology. 1998; 26(1): p. 52-57.

70. Cynthia AN. Drug induced nephrotoxicity. American family physician. 2008; 78(6): p. 743-750.

71. George BH. Management of acute and chronic renal failure in the newborn. Seminars in neonatology. 2003; 8: p. 325-334.

72. Jedage HD MK. Phytochemical, pharmacological evaluation of Morinda pubescens JE Sm. bark extract for nephroprotective activity. Ayu. 2016;(3-4): p. 244.

73. Ahmad F ASAAOAMA.2, 6(2):4.. Phytochemical and Nephroprotective Activity of Eclipta prostrata against Gentamicin Induced Nephrotoxicity in Wistar Rats. International Journal of Pharma Research and Health Sciences. .

74. H. D. Jedage KPM. PHYTOCHEMICAL, PHARMACOLOGICAL EVALUATION OF SAPINDUS EMARGINATUS. IJPSR. 2016; 7(4) p. 1564-1571. 